DOI: $10.17516 / 1997-1370-0680$

УДК 330.59

\title{
Subjective Poverty and Material Deprivation in Three Post-Soviet Countries
}

\author{
Elena E. Grishina* and Elena A. Tsatsura \\ Russian Presidential Academy \\ of National Economy and Public Administration \\ Moscow, Russian Federation
}

Received 29.07.2020, received in revised form 29.08.2020, accepted 09.11.2020

\begin{abstract}
This article provides an overview of different aspects of poverty in three PostSoviet countries: Russia, Armenia and Georgia. It looks into the material situation of households and subjective and deprivation poverty. Source data are the findings of three population surveys, conducted in the considered countries in 2017. The analysis shows a significant level of material deprivation among the population in the studied countries. The most vulnerable categories are rural population, 65+, and families with three or more children. Households in Armenia and Georgia are more dependent on farming and financial aid from their relatives than Russian households. Although the level of material deprivation in Russia is significantly lower compared with Armenia and Georgia, the level of relative subjective poverty in Russia is notably higher. It is likely due to higher inequality, which may point at risks of social instability. This indicates the need for new government policies in Russia that would focus on social development and reduction of inequality and social exclusion.
\end{abstract}

Keywords: Russia, Armenia, Georgia, financial situation, households, material deprivation, subjective poverty, well-being.

Research area: economy.

Citation: Grishina, E.E., Tsatsura, E.A. (2020). Subjective poverty and material deprivation in three Post-Soviet countries. J. Sib. Fed. Univ. Humanit. Soc. Sci., 13(11), 1746-1759. DOI: 10.17516/19971370-0680.

\footnotetext{
(C) Siberian Federal University. All rights reserved

* Corresponding author E-mail address: grishina@ranepa.ru ORCID: 0000-0001-8548-5497 (Grishina); 0000-0001-9142-2070 (Tsatsura)
} 


\section{Introduction}

Poverty is a rather complex phenomenon, and therefore to study it we need to look into a wide array of indicators, describing the numerous manifestations of poverty.

At present, the research community has reached a consensus that when analyzing poverty it is advisable to resort to not only monetary, but also subjective and deprivation dimensions of poverty. Researchers also point out that monetary indicators do not take account for such poverty-related issues as deprivation, shame and social exclusion (Ravallion, 2016). Moreover, the subjectively poor persons may not be viewed as poor according to objective poverty criteria, and vice versa, those who are classified as poor according to monetary criteria, may not actually suffer from subjective poverty (Ravallion, Lokshin, 2002).

P. Townsend suggested that poverty could be defined based on consumption deprivation (Townsend, 2002). He pioneered a relative deprivation approach, which covers material and social aspects, defining the subjective perception of poverty and how the society sees it (Townsend, 1979). At the same time, A. Sen defined poverty as deprivation of capabilities allowing to successfully function in the society (Sen, 1985). He insisted that poverty is a complex, multidimensional phenomenon, which needs to be analyzed in its entirety (Sen, 1999).

The United Nations define poverty as "a denial of choices and opportunities, a violation of human dignity. It means lack of basic capacity to participate effectively in society" (United Nations, 1998). Meanwhile, the Council of the European Union understands poverty as "persons, families and groups of persons whose resources (material, cultural and social) are so limited as to exclude them from the minimum acceptable way of life in the Member State in which they live" (Council of the EU, 1984).

Eurobarometer survey showed that about a quarter of EU respondents view poverty as a lack of resources to participate in the social life, and the same amount believe that poverty means dependency on any kind of social aid (European Commission, 2010). However, only $18 \%$ believe that poor means the people below poverty line, and $17 \%$ said that poverty means not having enough to cover basic essentials.

In Europe, multidimensional indicator AROPE (At risk of poverty or social exclusion) is used to evaluate the efficiency of anti-poverty programs. It takes account of such factors as monetary poverty, severe material deprivation and labor exclusion (Guio et al., 2012) In terms of this indicator, severe material deprivation is calculated as a share of population that cannot afford at least four of the following nine items: to pay their rent, mortgage or utility bills; to keep their home adequately warm; to face unexpected expenses; to eat meat or proteins regularly; to go on holiday; a television set; a washing machine; a car and a telephone.

The advantage of material deprivation indicators is that they recognize economic grievances, which are overlooked by the monetary poverty indicators. Besides, they allow easy cross-country comparisons, since they don't require addressing the disparities in prices, inflation and purchasing power parity (United Nations, 2017).

Subjective poverty perceptions are an important indicator of poverty too, as they allow to take into account what the people in need themselves think about poverty, identify the risks of poverty and seek mechanisms to reduce it. Subjective poverty indicators may help identify the weight of different attributes of wellbeing and threshold below which people judge themselves to be poor (Ravallion, 2012). Analyzing subjective perceptions of poverty in the population may bring us to understand to what extent the objective dimensions of poverty match public opinions on the matter. By participating in poverty analysis, low-income segments of the population give researchers a better understanding of poverty and have a chance to influence policymaking (Chambers, 1997). Subjective poverty may be approached from different angles, for example, households unable to make ends meet, households with a low position on the "poor to rich" scale, or households, which have low self-reported income level (Noll, Weick, 2014; European Commission, 2010; Van Praag, 1968).

This paper intends to analyze economic conditions, subjective poverty and materi- 
Table 1. GDP per capita, poverty and inequality in considered countries

\begin{tabular}{|l|c|c|c|}
\hline & Armenia & Georgia & Russia \\
\hline GDP per capita (2011 PPP \$) & 9,178 & 10,152 & 24,791 \\
\hline Human Development Index $^{1}$ & 0.760 & 0.786 & 0.824 \\
\hline Poverty headcount ratio at \$5.50 a day (2011 PPP), \% of population $^{3}$ & 50.4 & 42.9 & 2.3 \\
\hline GINI index & 37.4 & 36.4 & 37.5 \\
\hline
\end{tabular}

Sources: 1.-2. - UNDP. Human Development Report, 2019; 3. - World Bank. Poverty and Equity Database; Notes: time periods: 1. Armenia, Georgia - 2018, Russia - 2017; 2.-3. - 2018.

al deprivation among the population of three former USSR states: Russia, Armenia and Georgia. Despite their shared past, the current financial situation in these three countries varies significantly. The World Bank classifies Armenia, Georgia and Russia as upper-middle-income countries. But in Russia GDP per capita more than double the levels in Armenia and Georgia. Therefore, it is not surprising that the percentage of the population living on less than $\$ 5.50$ a day at 2011 international prices in Russia is significantly lower than in Armenia and Georgia (2.3\% compared to $50.4 \%$ and $42.9 \%$ ). At the same time, the level of income inequality in the considered countries is high and the Gini index in Russia is higher than in Armenia and Georgia (Table 1).

At the same time, poverty is viewed as a grave problem in all these countries. According to sociological surveys (Levada-Center, 2018; Caucasus Research Resource Centers, 2017), nearly $40 \%$ of respondents in Armenia and more than $40 \%$ in Georgia and Russia believe that poverty is one of the most urgent and serious problems faced by their country.

\section{Methods}

Source data are the findings of three population surveys, conducted in 2017. The data on Armenia and Georgia was retrieved from "Caucasus Barometer" 2017, the Caucasus Research Resource Centers (Caucasus Research Resource Centers, 2017). The source of the Russian data is the Regular National Representative Survey of the Demographic, Social and Economic Behavior of the Population "Person, Family, Society" 2017 (Russian Presidential Academy..., 2017). "Caucasus Barometer" is an annual survey about socio-economic issues and political attitudes conducted by the Caucasus Research Resource Centers of Armenia and Georgia. The data is representative nationwide. The population surveyed is persons aged 18 and above, excluding the people living in territories affected by military conflicts (South Ossetia and Abkhazia). The sample size is 1,648 respondents in Armenia and 2,379 respondents in Georgia. The survey mode is computer-assisted personal interview. The survey data is weighted.

"Person, Family, Society" is a representative survey on Russia's adult population aged 18 and above. The survey is designed to study family demography, reproductive behavior, households' socioeconomic standing, and the quality of public health. Sample size $-9,605$ respondents. The survey is implemented through computer-assisted telephone interviews. The survey data is weighted.

This study analyzed households' economic conditions based on self-reported ability to buy food, clothes and durable goods, incidence of borrowing money to buy food, subjective assessment of household's standing compared with other households in the country, availability of different sources of income and such essential home appliances as refrigerator, washing machine and PC. The analysis was focused both on the countries overall, and on different segments of the population in each country, including urban and rural population, persons living with children under 18; adults aged 18 to 64, and the elderly aged 65 and above.

The economic situation of households is estimated based on the respondents' answer to the question as follows: "Which of the following statements best describes the current economic situation of your household?" 
Among other, the analysis identified the share of respondents, whose answer to the question above was: "Money is not enough for food" and "Money is enough for food only, but not for clothes".

In the case of Armenia and Georgia, incidence of borrowing money to buy food was analyzed by means of the following question: "In the past 6 months, how often has your household borrowed any money to buy food?" In Russia, this question was slightly rephrased: "Have you borrowed money to buy food or bought it on credit in the past 12 months?"

The relative economic standing of household in Armenia and Georgia is assessed based on the respondents' answer to the question as follows: "Let's imagine there is a 10-step ladder reflecting the economic standing of all households in your country today. The first rung of this ladder corresponds to the lowest possible economic position in the society, while the 10th rung corresponds to the highest possible position. On which rung of this ladder do you think your household currently stands?" In Russia, the relative economic standing of household was assessed based on the respondents' answer to the following question: "Let's imagine there is a 9-step ladder, where the poorest people take the lowest rung, and the richest are on the highest. Which rung would you be on?" The answers given on a 10-point scale by respondents in Armenia and Georgia were recoded to 5-point scales - options 1 and 2 are coded as 1 , options 3 and 4 as 2 and so on. As for Russian respondents, the 9-point scale was recoded to 5 -point scales - option 5 is coded as 3 , options 1 and 2 are coded as 1, options 3 and 4 as 2 and so on.

In Armenia and Georgia, household income sources were assessed based on the respondents' answer to the question as follows: "Many households obtain income from several sources. I will read out several possible sources of income and please, tell me whether your household had monetary income from each of these sources in the last 12 months. Please think about the income of all members of your household". In Russia, the question was phrased as follows: "Please tell me, which sources of income does your household have - paid job, subsistence farming, retirement pension, social benefits/scholarship, aid from other persons or any other source of income? (please tick all that apply)"

Among other, the analysis was designed to calculate the share of respondents, who reported that their household does not have a working fridge (including freezer), automatic washer and PC (including a laptop).

The reliability of the relationships between the considered variables is checked by the Chisquare Test and the Mann-Whitney Test. The presented results are significant at $5 \%$ significance level.

\section{Results}

Survey findings indicate that the share of extremely poor persons, living in households that don't have enough money even to buy food is only $3 \%$ in Russia, compared with over $20 \%$ in Armenia and Georgia (Table 2). $25 \%$ of households in Russia can afford to buy food, but not clothes. In Armenia and Georgia, the share of such households is higher - over $30 \%$. Overall, almost $30 \%$ of the Russian population and over $50 \%$ of the people in Armenia and Georgia do not have enough money to buy clothes.

In all the three countries, rural areas have a higher share of persons living in a household that can afford food, but not clothes (in Russia, it's $30 \%$ against $25 \%$, in Armenia - $41 \%$ against $37 \%$; in Georgia - $35 \%$ against $27 \%$ ). Meanwhile, in Armenia, urban residents are more likely to not have enough money to buy food ( $24 \%$ against $19 \%$ ), whereas in Georgia, the share of such households is virtually equal among urban and rural population (21-22\%). It should be noted that in Russia, this figure is significantly lower both in the cities and rural areas $(3-5 \%)$.

Analysis of specific population segments reveals that respondents in Armenia and Georgia, who live in a childless household, more frequently reported that they did not have enough money to buy food than the respondents who live with children under 18 (26\% and $26 \%$ against $19 \%$ and $15 \%$, respectively). In Russia, the factor of children did not make any difference (3\%). 
Table 2. Respondents' views on economic situation of their household, \%

\begin{tabular}{|c|c|c|c|}
\hline & Armenia & Georgia & Russia \\
\hline Money is not enough for food & 23 & 22 & 3 \\
\hline Money is enough for food only, but not for clothes & 38 & 30 & 26 \\
\hline $\begin{array}{l}\text { Money is enough for food and clothes, but not enough for expensive } \\
\text { durables }\end{array}$ & 30 & 36 & 43 \\
\hline We can afford to buy some expensive durables & 6 & 8 & 22 \\
\hline We can afford to buy anything we need & 1 & 3 & 4 \\
\hline $\mathrm{DK} / \mathrm{RA}$ & 2 & 1 & 1 \\
\hline Total & 100 & 100 & 100 \\
\hline
\end{tabular}

Source: authors' calculations based on "Caucasus Barometer" 2017 and "Person, Family, Society" 2017.

Note: DK - hereinafter - don't know; RA - hereinafter - refuse to answer; HH - hereinafter - households; y/o - hereinafter - years old

However, in Armenia and Russia, multichild households are experiencing more serious material deprivation, than households with one child. Thus, in these countries, persons living in a household with three children and more are more likely to report that their household's financial situation allows them to buy food, but not clothes, than households with one child (39 \% against $26 \%$ in Russia; $43 \%$ against $33 \%$ in Armenia). At the same time, material deprivation among families with different number of children does not vary significantly (28-29\%).

In Russia and Georgia, households with only one adult aged 18 to 64 are more likely to report that they have money to buy food, but not for clothes, compared with households with several adults (29\% against $24-25 \%$ in Russia; $34 \%$ against 29 and $24 \%$ ). Besides, in Armenia and Georgia, one-adult households have a significantly higher level of poverty, reporting not enough money even to buy food, compared with multi-adult households (30\% in Armenia and $28 \%$ in Georgia against $15-16 \%$, respectively).

In all the three countries, people aged 65 and above are more likely to report that they only have enough money to buy food, or even that can be a problem. Notably, this is the case with slightly over a third of respondents in Russia living in households fully made of persons aged 65+, but in Armenia and Georgia this figure rises to nearly $90 \%$ and nearly $80 \%$, respectively (Table 3 ).
Scarcity of money among the population, when people cannot even cover their basic needs, i.e. food and clothes, translates into a third of respondents and more living in households, that have borrowed money to buy food (Table 4). Rural people are more likely to borrow money for food than urban residents.

In Russia and Armenia, households with children under 18 are slightly more likely to have to borrow money for food than the population in general. Even families in need try not to economize on their children's nutrition. In all the three countries, borrowing money for food is the highest among the households with $3+$ children (Table 5 ).

In Armenia and Georgia, the share of households that borrow money for food is the same, regardless if the household includes persons aged $65+$ or not $(39 \%$ and $41 \%$ in Armenia; $49 \%$ and $50 \%$ in Georgia). However, in Russia, households with elderly persons are significantly less likely to borrow money for food $-25 \%$ against $33 \%$ for all households.

Households' material deprivation can also be described by looking into the lack of different kinds of durable household goods.

Thus, in Russia, fewer than $5 \%$ respondents said they don't have a refrigerator, $5 \%$ don't have a washing machine, and $21 \%$ don't have a PC or laptop (Table 6). Figures are higher in Armenia and Georgia: $8 \%$ and $11 \%$ don't have a refrigerator, $21 \%$ and $27 \%$ don't have 
Table 3. Share of people who evaluated the economic situation of their household as "Money is not enough for food" and "Money is not enough for clothes", in households with and without adults of $65+$ years old, $\%$

\begin{tabular}{|c|c|c|c|}
\hline & & Money is not enough for food & $\begin{array}{l}\text { Money is enough } \\
\text { for food only, but not for clothes }\end{array}$ \\
\hline \multirow{3}{*}{ Armenia } & HH without adults $65+$ & 18 & 38 \\
\hline & HH with adults $65+$ & 30 & 39 \\
\hline & HH consists of adults $65+$ & 47 & 41 \\
\hline \multirow{3}{*}{ Georgia } & HH without adults $65+$ & 19 & 28 \\
\hline & HH with adults $65+$ & 25 & 34 \\
\hline & HH consists of adults $65+$ & 37 & 41 \\
\hline \multirow{3}{*}{ Russia } & HH without adults $65+$ & 3 & 26 \\
\hline & HH with adults $65+$ & 3 & 28 \\
\hline & HH consists of adults $65+$ & 3 & 33 \\
\hline
\end{tabular}

Source: authors' calculations based on “Caucasus Barometer” 2017 and “Person, Family, Society” 2017.

Table 4. Share of people, living in households that borrow money for food, in different areas, \%

\begin{tabular}{|c|c|c|c|}
\hline & Armenia & Georgia & Russia \\
\hline Total & 40 & 50 & 33 \\
\hline Urban area & 35 & 47 & 29 \\
\hline Rural area & 52 & 54 & 45 \\
\hline
\end{tabular}

Source: authors' calculations based on “Caucasus Barometer” 2017 and “Person, Family, Society” 2017.

Table 5. Share of people, living in households that borrow money for food, households with different number of children, \%

\begin{tabular}{|c|c|c|c|}
\hline & Armenia & Georgia & Russia \\
\hline HH with kids 0-17 y/o & 46 & 51 & 39 \\
\hline HH with 1 kid & 38 & 51 & 41 \\
\hline HH with 2 kids & 44 & 49 & 55 \\
\hline HH with 3+ kids & 67 & 60 & 36 \\
\hline
\end{tabular}

Source: authors' calculations based on “Caucasus Barometer” 2017 and “Person, Family, Society” 2017.

a washing machine, and $41 \%$ and $46 \%$ don't have a PC or laptop.

In all the studied countries, rural households are more likely to not have a PC, than urban residents. In Armenia and Georgia, at least $30 \%$ of rural people don't have a washing machine, compared with less than $20 \%$ among urban residents.

Households without children under 18 are more likely to not have a PC, than households with minors in it $(27 \%$ against $12 \%$ in Russia; $47 \%$ against $34 \%$ in Armenia; and $59 \%$ against $29 \%$ in Georgia). Besides, in Armenia and Georgia households without children under 18 are less likely to have a washing machine, than households with minors $(26 \%$ against $16 \%$ in Armenia; $34 \%$ against $17 \%$ in Georgia).

Multiple-children families in Russia and Armenia are more likely to not have a PC or 
laptop, than other households with children (22\% against $11 \%$ in Russia; and $44 \%$ against $31-33 \%$ in Armenia). Besides, in Armenia, multiple-children households are more likely to also not have a washing machine (20\% against $15 \%$ ). However, in Georgia, households with different number of children didn't show significant differences when it comes to owing a washing machine and a PC.

In all the three countries, households with one adult (aged 18 to 64) were more likely to not have a PC and a washing machine than households with multiple adults in the same age.

In Armenia, Georgia and Russia, households with adults aged 65 and above are more likely to not have a PC, than households without any members of this age $(32 \%$ against $18 \%$ in Russia; $49 \%$ against $36 \%$ in Armenia; and $57 \%$ against $37 \%$ in Georgia). In all countries, not having a PC is the highest among households made of persons aged 65 and above (56 \% in Russia, $73 \%$ in Armenia, and $89 \%$ in Georgia). Besides, in Armenia and Georgia, households with members aged 65 and above are more likely to not have a washing machine, than households that don't have members of this age $(25 \%$ against $19 \%$ in Armenia; $32 \%$ against $23 \%$ in Georgia).

Speaking of the relative economic situation of their households, more than $20 \%$ of respondents in Russia said it's "the lowest", whereas in Armenia and Georgia the share of such respondents was approximately half as high - about $10 \%$ (Table 7). Thus, although the level of material deprivation of households in Russia is significantly lower than Armenia and Georgia, the level of relative subjective poverty is significantly higher. This can be due to a substantial inequality in Russia and high awareness of inequality in the population.

Analyzing the share of respondents who evaluate their household's economic situation the lowest across different population categories, it can be observed that in rural areas of Russia and Armenia it is higher than in the cities $(27 \%$ against $20 \%$ in Russia; $13 \%$ against $8 \%$ in Armenia). However, Georgia does not show significant differences in the level of relative subjective poverty between rural and urban residents (11-13\%).

Table 6. Share of people who reported that their household doesn't have refrigerator, automatic washing machine or personal computer, \%

\begin{tabular}{|c|c|c|c|}
\hline & No refrigerator & No washing machine & No personal computer \\
\hline Armenia & 8 & 21 & 41 \\
\hline Georgia & 11 & 27 & 46 \\
\hline Russia & 1 & 5 & 21 \\
\hline
\end{tabular}

Source: authors' calculations based on “Caucasus Barometer” 2017 and “Person, Family, Society” 2017.

Table 7. Respondents' views on relative economic standing of their household, \%

\begin{tabular}{|c|c|c|c|}
\hline & Armenia & Georgia & Russia \\
\hline Lowest & 10 & 12 & 22 \\
\hline 2 & 29 & 31 & 21 \\
\hline 3 & 45 & 45 & 9 \\
\hline 4 & 12 & 10 & 1 \\
\hline Highest & 1 & 1 & 100 \\
\hline DK/RA & 3 & 1 & 2 \\
\hline Total & 100 & 100 & \\
\hline
\end{tabular}

Source: authors' calculations based on "Caucasus Barometer" 2017 and “Person, Family, Society” 2017. 
Households with three children and more from Russia and Armenia are more likely to say that their economic situation is the worst possible, compared with households with fewer children (24\% against $17-18 \%$ in Russia; $17 \%$ against $7-9 \%$ in Armenia). However, Georgia does not show significant differences in the level of relative subjective poverty between households with different number of children.

At the same time, in all the three countries the level of relative subjective poverty of households with just one adult aged 18 to 64 is higher compared with households with two and more adults of the same age (27\% against 18-19\% in Russia, $17 \%$ against 7-10 \% in Georgia; finally, in Armenia, the gap is the lowest - $12 \%$ against $10 \%$ for households with 2 adults and $6 \%$ for households with 3 adults).

The level of relative subjective poverty among households, consisting of persons aged 65 and above, is significantly higher compared with households with no members of that age (33\% against $19 \%$ in Russia, $17 \%$ against $9 \%$ in Armenia; and $20 \%$ against $12 \%$ in Georgia).

Differences in households' economic conditions in the reviewed countries may be explained by their income composition. Thus, nearly $80 \%$ of the respondents in Russia mentioned employment income as one of the sources of income for their household, whereas the share of such respondents in Armenia and Georgia as of 2017 was significantly lower, at about $50 \%$ (Table 8). Therefore, employment plays a more substantial part as an income source for households in Russia, compared with Armenia and Georgia.

By contrast, in Armenia and Georgia, the share of respondents, who named farming as a source of their household's income was twice as high, and the share of those, who take money from their relatives, was more than thrice as high as in Russia. Besides, Armenia and Georgia have a higher share of households that name pensions and social benefits as an income source.

In all the reviewed countries, rural households are more likely to have income from farming and less likely to have employment income than their urban counterparts. In Russia and Georgia, rural households are more likely to have such source of income as pensions and social benefits, than city households: $58 \%$ against $64 \%$ and $50 \%$ against $56 \%$, respectively. In Armenia and Georgia, the share of city households that receive financial aid from their relatives is higher than among rural households (36\% and $35 \%$ against $31 \%$ and $28 \%$, respectively).

In all the reviewed countries, households with three children and more are more likely to name pensions and social benefits and farming as a source of income compared with households with fewer children (Table 9).

In Armenia and Georgia, households with three children and more are a little less likely to have employment income compared with households with fewer children, whereas in Russia, households with different number of children did not report significant differences as to the availability of employment income.

In all the reviewed countries, households with two and more persons aged 18 to 64 are more likely to have employment income and less likely to receive pensions and social benefits (Table 10).

Besides, in Armenia and Georgia, such households are more likely to have farming in-

Table 8. Share of people, who reported salaries, pensions, benefits, sales of agricultural products or money from relatives as the sources of household income, \%

\begin{tabular}{|c|c|c|c|c|}
\hline & Salaries & Pensions or benefits & $\begin{array}{c}\text { Sales of agricultural } \\
\text { products }\end{array}$ & $\begin{array}{c}\text { Money } \\
\text { from relatives }\end{array}$ \\
\hline Armenia & 50 & 60 & 22 & 35 \\
\hline Georgia & 49 & 59 & 24 & 32 \\
\hline Russia & 78 & 52 & 10 & 3 \\
\hline
\end{tabular}

Source: authors' calculations based on “Caucasus Barometer” 2017 and “Person, Family, Society” 2017. 
Table 9. Share of people who reported salaries, pensions, benefits, sales of agricultural products or money from relatives as the sources of household income,

in households with different number of children, \%

\begin{tabular}{|c|c|c|c|c|c|}
\hline & & Salaries & $\begin{array}{c}\text { Pensions or } \\
\text { benefits }\end{array}$ & $\begin{array}{c}\text { Sales of agricultural } \\
\text { products }\end{array}$ & $\begin{array}{c}\text { Money } \\
\text { from relatives }\end{array}$ \\
\hline \multirow{3}{*}{ Armenia } & $1 \mathrm{kid}$ & 66 & 43 & 21 & 28 \\
\hline & 2 kids & 61 & 57 & 29 & 30 \\
\hline & $3+$ kids & 51 & 71 & 36 & 32 \\
\hline \multirow{3}{*}{ Georgia } & $1 \mathrm{kid}$ & 64 & 51 & 21 & 31 \\
\hline & 2 kids & 61 & 51 & 28 & 28 \\
\hline & $3+$ kids & 56 & 61 & 35 & 26 \\
\hline \multirow{3}{*}{ Russia } & $1 \mathrm{kid}$ & 92 & 39 & 9 & 5 \\
\hline & 2 kids & 92 & 38 & 9 & 5 \\
\hline & $3+$ kids & 88 & 60 & 16 & 7 \\
\hline
\end{tabular}

Source: authors' calculations based on “Caucasus Barometer” 2017 and “Person, Family, Society” 2017.

Table 10. Share of people who reported salaries, pensions, benefits, sales of agricultural products or money from relatives as the sources of household income, in households with different number of adults, \%

\begin{tabular}{|c|c|c|c|c|c|}
\hline & & Salaries & $\begin{array}{l}\text { Pensions or } \\
\text { benefits }\end{array}$ & $\begin{array}{c}\text { Sales of agricultural } \\
\text { products }\end{array}$ & $\begin{array}{c}\text { Money } \\
\text { from relatives }\end{array}$ \\
\hline \multirow{3}{*}{ Armenia } & 1 adult $18-64$ y/o & 36 & 61 & 12 & 52 \\
\hline & 2 adults $18-64$ y/o & 56 & 53 & 22 & 28 \\
\hline & $3+$ adults $18-64$ y/o & 70 & 50 & 32 & 26 \\
\hline \multirow{3}{*}{ Georgia } & 1 adult $18-64$ y/o & 36 & 62 & 18 & 44 \\
\hline & 2 adults $18-64$ y/o & 59 & 48 & 26 & 29 \\
\hline & $3+$ adults $18-64 \mathrm{y} / \mathrm{o}$ & 66 & 50 & 31 & 23 \\
\hline \multirow{3}{*}{ Russia } & 1 adult $18-64$ y/o & 63 & 56 & 9 & 5 \\
\hline & 2 adults $18-64$ y/o & 86 & 42 & 10 & 3 \\
\hline & $3+$ adults $18-64 \mathrm{y} / \mathrm{o}$ & 91 & 52 & 13 & 2 \\
\hline
\end{tabular}

Source: authors' calculations based on “Caucasus Barometer" 2017 and “Person, Family, Society” 2017.

come and less likely to take money from their relatives.

In Russia, same as in Georgia and Armenia, the share of receivers of pensions and social benefits is significantly higher and the share of salary-receivers is lower among households made of persons aged 65 and above, compared with households that don't have third-age members (Table 11). Thus, in Russia and Georgia only $14 \%$ and $12 \%$ households, which consist of persons aged 65 and above, reported employment income, while in Armenia this figure was even lower $-4 \%$.
Besides, in Armenia and Georgia households consisting of persons aged 65 and above were more likely to receive financial aid from their relatives, than households which don't have third-age members.

\section{Discussion and conclusion}

Our study shows that the level of material deprivation is lower in Russia compared with Armenia and Georgia. The percentage of the population living on less than $\$ 5.50$ a day at 2011 international prices in Russia is significantly lower than in Armenia and Georgia. 
Table 11. Share of people who reported salaries, pensions, benefits, sales of agricultural products or money from relatives as the sources of household income, in households with and without adults aged $65+, \%$

\begin{tabular}{|c|c|c|c|c|c|}
\hline \multirow{2}{*}{ Armenia } & Salaries & $\begin{array}{c}\text { Pensions } \\
\text { or benefits }\end{array}$ & $\begin{array}{c}\text { Sales of agricultural } \\
\text { products }\end{array}$ & $\begin{array}{c}\text { Money } \\
\text { from relatives }\end{array}$ \\
\cline { 2 - 6 } & HH without adults 65+ & 59 & 35 & 23 & 35 \\
\hline \multirow{3}{*}{ Georgia } & HH without adults 65+ & 56 & 31 & 5 & 46 \\
\cline { 2 - 6 } & HH consists of adults 65+ & 12 & 97 & 12 & 33 \\
\hline \multirow{2}{*}{ Russia } & HH without adults 65+ & 85 & 40 & 10 & 39 \\
\cline { 2 - 6 } & HH consists of adults 65+ & 14 & 100 & 13 & 4 \\
\hline
\end{tabular}

Source: authors' calculations based on “Caucasus Barometer” 2017 and “Person, Family, Society” 2017.

Although the demographic profile of the population with the highest deprivation is similar across the three countries, there are also certain differences. Thus, Russia presents higher risks of material deprivation for rural households and those having multiple children. In Armenia, material deprivation is the highest in households with no children under 18 and multiple-children households. In Georgia, the most vulnerable groups are rural households and households with no children under 18 . Besides, households with persons of 65 and above showed a high level of material deprivation in all the reviewed countries. Higher risks of poverty for the rural population, pensioners and families with many children in former Soviet republics noted in several studies (Food and Agriculture Organization of the United Nations, 2007; Simai, 2006; Mikhalev, 2000). A relatively high level of poverty remains in remote areas due to structural and institutional problems (Simai, 2006).

Where the population does not have enough money to cover such essentials as food and clothes, as a result, in the countries studied about half of the respondents belonged to households that borrow money to buy food. Rural people are more likely to borrow money for food than their city counterparts. In Russia and Armenia, money borrowers are likely to be families with children, especially multiple-children households.

The availability of durable goods, such as washing machine and PC, also varies across the countries studied. Thus, in Russia only
$5 \%$ of the respondents said they didn't have a washing machine, compared with more than $20 \%$ in Georgia and Armenia. A little more than $20 \%$ of Russian respondents don't have a PC, while in Armenia and Georgia this figure is over $40 \%$. In all three countries, the population groups likely not to have a PC are: rural households, households with no children under 18; and especially households consisting of persons $65+$ and households with only one adult member aged 18-64. Besides, in Russia and Armenia, families with three and more children are more likely not to have a PC, compared with families with fewer kids. As mentioned in the Human Development Report, ICT penetration among the public in the counties of the Commonwealth of Independent States is not very high (United Nations Development Programme [UNDP], 2011). This restricts access to knowledge, information and participation in economic, political and social life. The low-income population often cannot afford a computer or internet and suffers from deprivation and limited asses to some public services.

Differences in households' economic conditions in the reviewed countries may be explained by their income composition. Thus, employment plays a more substantial part as an income source for households in Russia, compared with Armenia and Georgia. At the same time, households in Armenia and Georgia are more dependent on farming, financial aid from their relatives and social pensions and benefits. The large share of the population working in informal jobs and insecure labour conditions 
Table 12. Characteristics of considered countries

\begin{tabular}{|c|c|c|c|c|}
\hline & & Armenia & Georgia & Russia \\
\hline \multicolumn{2}{|l|}{ Education expenditure, $\% \mathrm{GDP}^{1}$} & 2.8 & 3.8 & 3.8 \\
\hline \multicolumn{2}{|l|}{ Health expenditure, $\%$ GDP $^{2}$} & 9.9 & 8.4 & 5.3 \\
\hline \multicolumn{2}{|c|}{ Social assistance expenditure, $\% \mathrm{GDP}^{3}$} & 1.4 & 7.0 & 1.9 \\
\hline \multicolumn{2}{|c|}{ Education quality, $\%$ satisfied $^{1}$} & 52 & 51 & 50 \\
\hline \multicolumn{2}{|l|}{ Health care quality, $\%$ satisfied $^{1}$} & 35 & 51 & 34 \\
\hline \multicolumn{2}{|c|}{ Incomes should be made more equal, \% strongly support ${ }^{4}$} & 16 & 6 & 34 \\
\hline \multirow{2}{*}{$\begin{array}{l}\text { Feeling safe, \% answering } \\
\text { "yes"1 }\end{array}$} & Female & 83 & 76 & 48 \\
\hline & Male & 96 & 83 & 69 \\
\hline \multirow{2}{*}{$\begin{array}{l}\text { Freedom of choice, \% answer- } \\
\text { ing "yes"' }\end{array}$} & Female & 78 & 71 & 68 \\
\hline & Male & 81 & 76 & 68 \\
\hline \multicolumn{2}{|c|}{ Trust in national government, \% answering "yes"'1 } & 67 & 30 & 46 \\
\hline
\end{tabular}

Sources: 1.-2. - UNDP. Human Development Report 2019; 3. - World Bank. ASPIRE indicators at a glance; 4. - World Values Survey Wave 6.

Notes: time periods: 1. - the most recent year available during 2013-2018; 2. - 2016; 3. Armenia - 2014; Georgia 2013; Russia - 2015; 4. Armenia and Russia - 2011; Georgia - 2014

has also led to higher social exclusion outcomes (UNDP, 2011). Although subsistence agriculture is an important survival strategy for people in rural areas and improves the material situation of rural families, it cannot fully mitigate their deprivations (UNDP, 2011).

Although the level of material deprivation in Russia is significantly lower compared with Armenia and Georgia, the level of relative subjective poverty in Russia is notably higher.

Karabchuk and Salnikova (Karabchuk, Salnikova, 2016) also found that in the countries of Central Asia the level of subjective satisfaction with the financial situation is higher than in Russia but the level of objective wellbeing is lower. This can be explained by the fact that self-evaluation is formed in comparison with the position of the reference group (Danzer et al., 2014). Inequality in Russia is higher and the population compares their financial situation with high-income groups.

Data from the Human Development Report shows that the high inequality level in Russia led more than one third of the population strongly support the statement that incomes should be made more equal (Table 12). The negative attitude to inequality is significantly higher in Russia than in Armenia and Georgia. Income inequality in post-commu- nist countries has increased after the transition from a centrally planned to a market economy (Rose, Viju, 2014). As Ravallion (Ravallion, 1997) mentioned, high inequality can reduce economic growth and limit the effect of economic growth on poverty reduction.

The higher level of relative subjective poverty in Russia may also point at the risks of social instability and insufficient social mobility. The lack of upward social mobility in Russia is mentioned by Shkaratan and Iastrebov (Shkaratan, Iastrebov, 2012).

The share of expenditures on health, education and social assistance in Russia is relatively low (Table 12). Only one-third of Russians is satisfied with health care quality and half of the Russian citizens is satisfied with education quality. The share of people feeling safe and satisfied with their freedom to choose in Russia is lower than in Armenia and Georgia. In addition, less than half the population in Russia trusts in the national government. In comparison, in Armenia this share is more than $60 \%$.

Weak governance and law enforcement foster social exclusion. People have low levels of trust in institutions and think that the state is not fully discharging its responsibilities. Golinowska et al. (Golinowska et al., 2009) 
pointed out that many postcommunist countries suffer from similar problems as weakness of non-governmental organizations; relatively low social security benefits; high corruption; high level of deprivation and social exclusion of population. The high level of social exclusion could create aggravated social tensions and unrest (UNDP, 2011).

This indicates the need for new government policies in Russia that would focus on social development and reduction of social inequality and exclusion. Development of effective protection policies, greater spending on health and education, ensuring access to services, enhancement of voluntary sector and community participation in local projects will contribute to social inclusion.

\section{Acknowledgement}

The article was written based on the RANEPA state assignment research programme.

\section{References}

Caucasus Research Resource Centers (2017). “Caucasus Barometer” 2017, available at: https://caucasusbarometer.org/en/datasets/ (accessed 29 July 2020).

Chambers, R. (1997). Whose reality counts? Putting the last first. London, UK, Intermediate Technology Publications.

Council of the European Union (1984). 85/8/EEC: Council Decision of 19 December 1984 on specific Community action to combat poverty, available at: https:/eur-lex.europa.eu/legal-content/EN/TXT/HTML/?uri=CELEX:31985D0008\&from=EN (accessed 29 July 2020).

Danzer, A.M., Dietz, B., Gatskova, K., Schmillen, A. (2014). Showing off to the new neighbors? Income, socioeconomic status and consumption patterns of internal migrants. In Journal of comparative economics, 42 (1), 230-245. DOI: 10.1016/j.jce.2013.05.002

Guio, A.C., Gordon, D., Marlier, E. (2012). Measuring material deprivation in the EU: Indicators for the whole population and child-specific indicators. Eurostat Methodologies and Working Papers, available at: https://ec.europa.eu/eurostat/documents/3888793/5853037/KS-RA-12-018-EN.PDF_(accessed 29 July 2020).

European Commission (2010). Poverty and social exclusion report. Special Eurobarometer 355, available at: https://ec.europa.eu/commfrontoffice/publicopinion/archives/ebs/ebs_355_en.pdf_accessed 29 July 2020).

Food and Agriculture Organization of the United Nations (2007). Growth, development and poverty reduction in Central Eurasia. Rome, FAO.

Golinowska, S., Hengstenberg, M., Zukonski, M. (2009). Diversity and commonality in European social policies: the forging of a European social model. Friedrich Ebert Stiftung, Warsaw, available at: https:// library.fes.de/pdf-files/bueros/warschau/06223.pdf (accessed 29 July 2020).

Karabchuk, T.S., Salnikova, D.V. (2016). O"ektivnoe i sub"ektivnoe blagopoluchie: opyt sravnitel'nogo analiza stran Central'noj Azii, Rossii i Belarusi [Objective and subjective well-being: a comparative analysis of Central Asian countries, Russia and Belarus]. In Sotsiologicheskie issledovaniya [Sociological Studies], 5, 96-109.

Levada-Center (2018). Social problems, available at: https://www.levada.ru/en/2018/10/12/the-socialproblems-which-most-concern-the-public/ (accessed 29 July 2020).

Mikhalev, V. (2000). Inequality and transformation of social structures in transitional economies. Research for Action series No. 52. Helsinki: UNU/WIDER, available at: https:/www.wider.unu.edu/sites/ default/files/rfa52.pdf (accessed 29 July 2020).

Noll, H.-H., Weick, S. (2014). Major disparities in households' ability to make ends meet. Comparative analyses of the material standard of living in the European Union. In Informationsdienst Soziale Indikatoren, 1-5, available at: https://www.gesis.org/fileadmin/upload/forschung/publikationen/zeitschriften/isi/ isi42-NollWeick-English.pdf_(accessed 29 July 2020).

Russian Presidential Academy of National Economy and Public Administration. (2017). Regular national representative survey of the demographic, social and economic behavior of the population "Person, 
Family, Society" 2017, available at: https://social.ranepa.ru/tsentry-i-instituty/institut-sotsialnogo-analiza-i-prognozirovaniya/issledovaniya/86-chelovek-semya-obshchestvo-2017 (accessed 29 July 2020).

Ravallion, M. (2016). Toward better global poverty measures. In The Journal of Economic Inequality, $14,227-248$

Ravallion, M. (2012). Poor, or just feeling poor? On using subjective data in measuring poverty. World Bank Policy Research Working Paper, No. 5968. Washington, D.C: The World Bank, available at: http:// documents.worldbank.org/curated/en/560421468152099804/pdf/WPS5968.pdf (accessed 29 July 2020).

Ravallion, M., Lokshin, M. (2002). Self-rated economic welfare in Russia. In European Economic Review, 46(8), 1453-1473. DOI: 10.1016/S0014-2921(01)00151-9

Ravallion, M. (1997). Can high-inequality developing countries escape absolute poverty? In Economics Letters, 56, 51-57.

Rose, S., Viju, C. (2014). Income inequality in post-communist Central and Eastern European countries. In Eastern Journal of European Studies, 5(1), 5-19.

Sen, A. (1985). Commodities and capabilities. Amsterdam, North-Holland.

Sen, A. (1999). Development as freedom. Oxford University Press, 366 p.

Shkaratan, O.I., Iastrebov, G.A. (2012). A Comparative analysis of the processes of social mobility in the USSR and in today's Russia. In Russian Education \& Society, 54(5), 24-64. DOI: 10.2753/RES10609393540502

Simai, M. (2006). Poverty and inequality in Eastern Europe and the CIS transition economies. DESA Working Paper No. 17, available at: https://www.un.org/esa/desa/papers/2006/wp17_2006.pdf (accessed 29 July 2020).

Townsend, P. (1979). Poverty in the United Kingdom: A survey of household resources and standards of living. London, Allen Lane and Penguin Books.

Townsend, P. (2002). Poverty, social exclusion, and social polarisation: The need to construct and international welfare state. In P. Townsend and D. Gordon (Eds.), World Poverty: New Policies to Defeat an Old Enemy. Bristol, UK: Policy Press.

Van Praag, B.M.S. (1968). Individual welfare functions and consumer behavior. Amsterdam, North-Holland.

United Nations (1998). Statement of commitment for action to eradicate poverty adopted by Administrative Committee on Coordination, available at: https://www.un.org/press/en/1998/19980520.eco5759.html (accessed 29 July 2020).

United Nations (2017). Guide on poverty measurement. United Nations Economic Commission for Europe, available at: https://www.unece.org/fileadmin/DAM/stats/publications/2018/ECECESSTAT20174. pdf_(accessed 29 July 2020).

United Nations Development Programme (2011). Beyond transition: towards inclusive societies. Regional human development report, available at: from https://en.unesco.org/inclusivepolicylab/sites/default/ files/clearinghouse/document/2016/11/Beyond \%20Transition- \%20Towards \%20Inclusive \%20Societies. pdf_(accessed 29 July 2020).

World Bank. International Comparison Program database. GNI per capita, PPP (current international \$), available at: https://data.worldbank.org/indicator/NY.GNP.PCAP.PP.CD (accessed 29 July 2020). 


\title{
Субъективная бедность и материальная депривация \\ в трех постсоветских странах
}

\section{Е.Е. Гришина, Е.А. Цацура}

Российская академия народного хозяйства и государственной службы при Президенте Российской Федерачии

Российская Федерация, Москва

\begin{abstract}
Аннотация. В статье рассматриваются различные аспекты бедности в трех постсоветских странах: России, Армении и Грузии. Исследуется материальное положение домохозяйств, показатели субъективной и деривационной бедности. Источником данных послужили обследования населения, проведенные в указанных странах в 2017 г. В результате исследования был выявлен существенный уровень материальных деприваций населения в рассматриваемых странах. Наиболее уязвимыми являются сельские жители, лица в возрасте $65+$, а также семьи с тремя и более детьми. В Армении и Грузии домохозяйства в большей степени зависят от доходов от личного подсобного хозяйства и помощи родственников. Несмотря на то что уровень материальной депривации в России существенно ниже, чем в Армении и Грузии, уровень относительной субъективной бедности в России существенно выше, что может быть обусловлено повышенным уровнем неравенства в России и может свидетельствовать о рисках социальной нестабильности. Это указывает на необходимость принятия в России дополнительных мер государственной политики, направленных на социальное развитие, сокращение неравенства и социальной исключенности.
\end{abstract}

Ключевые слова: Россия, Армения, Грузия, финансовое положение, домохозяйства, материальная депривация, субъективная бедность, благосостояние.

Научная специальность: 08.00.00 - экономические науки. 